\title{
Pengaruh Pendekatan Open ended Dan Pendekatan Problem posing Terhadap Peningkatan Kemampuan Berpikir Kreatif Matematika Siswa SMP Ditinjau Dari Gaya Kognitif
}

\author{
(The Effect Of Open ended Approach And Problem posing Approach On The Improvement \\ Of Junior High School Students' Ability Of Mathematic Creative Thinking Viewed From \\ Cognitive Style)
}

\author{
Novi Purnadewi ${ }^{1}$, Mustamin Anggo ${ }^{2}$, Baharuddin ${ }^{3}$ \\ ${ }^{1}$ Guru SMP Negeri 1 Konawe Sleatan, Alumnus Prodi Pendidikan Matematika PPS Universitas Halu Oleo \\ ${ }^{2}$ Dosen Pendidikan Matematika FKIP dan PPs Universitas Halu Oleo; Co-author: \\ mustaminanggo@gmail.com \\ ${ }^{3}$ Dosen FMIPA dan Pendidikan Matematika PPs Universitas Halu Oleo
}

\begin{abstract}
Abstrak: Penelitian ini merupakan penelitian eksperimen dengan tujuan untuk mengkaji dan menganalisis : (1) Perbedaan pengaruh pendekatan open ended dan pendekatan problem posing terhadap peningkatan kemampuan berpikir kreatif matematik siswa dengan gaya kognitif reflektif; dan (2) Perbedaan pengaruh pendekatan open ended pendekatan problem posing terhadap peningkatan kemampuan berpikir kreatif matematik siswa dengan gaya kognitif impulsif. Poopulasi dalam penelitian ini adalah seluruh siswa kelas VII SMPN 1 Konawe Selatan sebanyak 10 kelas. Pengambilan sampel kelas dilakukan dengan menggunakan dua teknik, yaitu purposive sampling. Sampel penelitian sebanyak 47 siswa. Pengambilan data dilakukan dengan cara memberi tes kemampuan berpikir kreatif matematika siswa sebelum dan setelah diberikan perlakuan, serta diberi gaya kognitif. Hasil penelitian ini adalah: (1) Tidak terdapat perbedaan pengaruh yang signifikan pendekatan open ended dan pendekatan problem posing terhadap peningkatan kemampuan berpikir kreatif matematik siswa dengan gaya kognitif reflektif; dan (2)Tidak terdapat perbedaan pengaruh yang signifikan pendekatan open ended pendekatan problem posing terhadap peningkatan kemampuan berpikir kreatif matematik siswa dengan gaya kognitif impulsif
\end{abstract}

Kata kunci: Kemampuan berpikir Kreatif, Pendekatan Open ended, Pendekatan Problem Posing, Gaya Kognitif

\begin{abstract}
This study was an experimental research which aimed to investigate and analyze: (1) the difference in the effect of open-ended approach and problem posing approach on the improvement of mathematic creative thinking ability gained by students with reflective cognitive style; and (2) the difference in the effect of open-ended approach and problem posing approach on the improvement of mathematic creative thinking ability gained by students with impulsive cognitive style. Population of the study included all students of class VII at SMPN 1 South Konawe, totaling 10 classes. Samples were 47 students which were determined using a purposive sampling technique. Data were acquired by administering a test, designed to measure students' mathematic creative thinking ability as well as their cognitive style, prior to and after treatment. Results of the study showed that: (1) there was no significant difference between open-ended and problem posing approaches in terms of the improvement of mathematic creative thinking ability showed by students with reflective cognitive style; (2) there was no significant difference between openended and problem posing approaches in terms of the improvement of students' mathematic creative thinking ability showed by students with impulsive cognitive style.
\end{abstract}

Keywords: Creative Thinking Ability, Open-Ended Approach, Problem posing Approach, Cognitive Style.

\section{PENDAHULUAN}

Kemampuan berpikir kreatif menjadi sebuah tuntutan seiring dengan semakin kompleksnya permasalahan kehidupan yang harus dihadapi manusia.
Pembangunan suatu bangsa tergantung dari sumber daya manusia. Sumber daya manusia ditentukan oleh pendidikan. Sumber daya manusia yang berkualitas 
diperlukan untuk menyelesaikan masalah yang dihadapi. Penyelesaian masalah membutuhkan suatu ide yang baru. Berpikir kreatif diperlukan dalam memunculkan suatu ide baru (Siswono, 2007). Pehkonen (1997) menyatakan bahwa berpikir kreatif diartikan sebagai suatu perpaduan antara berpikir logis dan berpikir divergen yang didasarkan pada intuisi tetapi masih dalam kesadaran. Berpikir kreatif sangat dibutuhkan dalam matematika karena berguna untuk merumuskan, menafsirkan, dan menyelesaikan model atau perencanaan pemecahan masalah. Hal tersebut diperkuat oleh pendapat Ginsburg dalam Singer dan Voica (2015) bahwa hakikat dari matematika bukan hanya menentukan jawaban yang benar tetapi berpikir kreatif.

Siswa Indonesia pada umumnya memiliki kemampuan pemecahan masalah kreatif yang masih sangat rendah, khususnya dalam menyelesaikan masalah matematika. Hal ini terlihat dari hasil tes PISA (Programme for International Student Assessment) tahun 2012 (literasi bahasa, matematika, dan sains). Tes PISA pada tahun 2012 dirancang untuk mengukur kemampuan siswa dalam pemecahan masalah kreatif khususnya terkait real-life problems. Pada tes terakhir ini Indonesia berada pada peringkat 64 dari 65 negara peserta PISA, turun 3 peringkat dari perolehan periode sebelumnya (OECD, 2012). Padahal kemampuan ini penting untuk dunia bisnis dan industri (Kay, 2003), yang salah satu tujuan pentingnya adalah mempersiapkan siswa kita dalam menghadapi masyarakat ekonomi ASEAN (MEA). Hal ini menunjukkan bahwa kemampuan pemacahan masalah kreatif (Students' Creative Problem Solving Ability) harus dilatih secara khusus dalam pembelajaran matematika di Indonesia.

Seorang guru dituntut agar tugas dan peranannya tidak hanya sebagai sumber informasi, melainkan sebagai fasilitator dan pendorong agar siswa dapat mengkontruksi sendiri pengetahuannya melalui berbagai aktivitas seperti masalah dalam kehidupanya sehari-hari, memfasilitasi siswa dalam menghubungkan pengetahuan awalnya dalam menyelesaikan suatu masalah. Namun sebagian besar guru masih menerapkan pembelajaran yang bersifat satu arah sehingga proses pembelajaran cenderung didominasi oleh guru. Siswa kurang diberikan kesempatan untuk memikirkan dan menemukan konsep sendiri. Hal ini mengakibatkan konsep yang dipelajari siswa cenderung tidak bertahan lama atau mudah hilang bahkan kadang-kadang siswa tidak mengerti atau tidak memahami sama sekali konsep yang sedang dipelajari.

Berdasarkan hasil observasi yang dilakukan di SMP N 1 Konawe Selatan, didapatkan bahwa meskipun sekolah tersebut sudah menggunakan Kurikulum 2013 dalam pelaksananya, guru tetap saja lebih sering mengajar dengan model ataupun pendekatan pembelajaran yang biasa digunakanya. Pembelajaran masih berpusat pada guru itu sendiri, sebagian besar siswa masih kesulitan dalam mengemukakan ide atau gagasanya dalam proses pembelajaran itu sendiri. Hal ini menyebabkan hanya kurang lebih $20 \%$ siswa yang dapat memahami materi yang diajarkan. Siswa lebih banyak diberikan soal-soal konseptual yang ada pada buku ajar, dan kurang diperkenalkan dalam menyelesaikan masalah-masalah konteks dalam menemukan atau menyelesaikan masalah. Kondisi ini membuat siswa kurang aktif dalam proses pembelajaran dan kesulitan dalam mencapai nilai ketuntasan yang diharapkan dan kreatifitas siswa tidak nampak. Meskipun guru belum mahir dalam menggunakan model pembelajaran baru atau mengembangkan pembelajaran aktif, namun kenyataanya siswa masih merasa lebih mudah menerima informasi materi pembelajaran seperti ini. 
Aktifitas pembelajaran matematika di Amerika yang direkomendasikan oleh National Council of Teachers of Mathematics (NCTM, 2000) yaitu pengajuan masalah. Pada kurikulum Cina yaitu Chinese National Curriculum Standards on Mathematics mewajibkan siswa dapat mengajukan dan memahami masalah matematika, mengaplikasikan pengetahuan dan keterampilan dasar untuk menyelesaikan masalah dan mengaplikasikannya (Bonotto dan Santo, 2015). Begitu juga pada kurikulum Italia yaitu Italian mathematics Union dan kementrian pendidikan Italia menyatakan pentingnya pengajuan masalah pada kurikulum matematika (Bonotto dan Santo, 2015).

Salah satu pendekatan pembelajaran yang dapat meningkatkan kreatifitas siswa dalam menyelesaikan masalah matematika adalah dengan pendekatan open ended dan pendekatan problem posing. Pendekatan pembelajaran ini secara umum masih sangat jarang diterapkan oleh guruguru di SMP N 1 Konawe Selatan, sehingga siswa belum terbiasa dalam menyelesaikan masalah-masalah yang memungkinkan mereka untuk menungkapkan ide-ide dalam menyelesaikan masalah matematika.

Dalam menginvestigasi kemampuan berpikir kreatif diperlukan sebuah alat, salah satunya pengajuan masalah. Pengajuan masalah telah lama diakui sebagai kegiatan yang sangat penting dalam penyelidikan ilmiah. Hal ini dikarenakan jika siswa mengajukan masalah yang akan diselesaikan maka mereka akan memiliki tanggung jawab untuk memperhatikan masalah dan menyelesaikan dengan cara yang benar. Pengajuan masalah juga membuat siswa mudah memahami soal karena mereka membuat soal sendiri sehingga akan berdampak pada kemampuan memecahkan masalah (NCTM, 2000). Pengajuan masalah dapat memunculkan ide kreatif siswa sehingga pengajuan masalah dapat digunakan untuk menilai berpikir kreatif. Silver (1997) menyatakan bahwa pengajuan masalah dalam pembelajaran matematika dapat berfungsi sebagai cara untuk meningkatkan kreativitas. Sedangkan pada pendekatan open ended siswa memiliki kesempatan lebih banyak dalam memanfaatkan pengetahuan dan keterampilan matematik secara komprehensif; siswa dengan kemampuan matematika rendah dapat merespon permasalahan dengan cara mereka sendiri; siswa secara implinsik termotivasi untuk memberikan bukti atau penjelasan; dan siswa juga memiliki pengalaman banyak untuk menemukan sesuatu dalam menjawab permasalahan.

Selain hal itu, perbedaan individu siswa perlu diperhatikan dalam meningkatkan pencapaian kemampuan masalah matematika siswa. Perbedaan tiap individu ini tentu saja akan berpengaruh terhadap kemampuan mengkonstruksi pengetahuan seseorang sehingga mampu memahami dan mengolah informasi yang diperoleh. Perbedaan di antara masing-masing individu dalam cara menyusun dan mengolah informasi sering dikenal dengan gaya kognitif. Gaya kognitif merupakan cara siswa menyusun dan mengolah informasi serta pengalaman pengalaman yang berasal dari alam sekitar (Amrina, 2004: 64). Gaya kognitif merupakan salah satu variabel kondisi belajar yang menjadi salah satu bahan pertimbangan dalam merancang pembelajaran (Bruce Joyce, 1992:241).

Cara pemecahan masalah yang digunakan seseorang saat memecahkan masalah cenderung berbeda karena dipengaruhi beberapa faktor, seperti gaya kognitif, yaitu cara individu dalam berpikir, mengingat, memecahkan masalah, membuat keputusan, mengorganisasi dan memproses informasi dari masalah-masalah yang dihadapi ( Abdul Karim). Pengetahuan tentang gaya kognitif dibutuhkan untuk merancang atau 
memodifikasi materi pembelajaran, tujuan pembelajaran, serta metode pembelajaran. Diharapkan dengan adanya interaksi dari faktor gaya kognitif, tujuan, materi, serta metode pembelajaran, hasil belajar siswa dapat dicapai semaksimal mungkin. Hal ini sesuai dengan pendapat beberapa pakar yang menyatakan bahwa jenis strategi pembelajaran tertentu memerlukan gaya belajar tertentu.

\section{METODE PENELITIAN}

Jenis penelitian ini adalah penelitian eksperimen semu (quasi eksperimental), karena pada pelaksanaannya menggunakan kelas eksperimen 1 dan kelas eksperimen 2. Pada kelompok eksperimen 1, peneliti memberi perlakuan pembelajaran dengan menggunakan pendekatan kontekstual open-ended. Penelitian ini dilaksanakan di SMP N 1 Konawe Selatan pada semester genap Tahun Ajaran 2016/2017 dengan sampel diambil dengan metode purposive sampling yaitu kelas VII C sebagai kelas Problem posing dan kelas VII D sebagai kelas open ended.

Instrumen pada penelitian ini terdiri dari soal tes kemampuan berpikir kreatif matematika siswa dengan jumlah soa sebanyak 4 butir soal dimana masingmasing soal mewakili satu indikator yaitu fluency, fleksibility, originality, dan elaborasi. Sedangkan untuk tes gaya kognitif digunakan tes gaya kognitif

\section{HASIL PENELITIAN}

Hasil analsisi deskripsi Peningkatan Kemampuan Berpikir Kreatif Matematika
Berdasarkan uraian tersebut di atas, peneliti termotivasi untuk melakukan penelitian yang berfokus pada penerapan pendekatan open ended dan pendekatan problem posing dalam pembelajaran matematika di kelas serta pengaruhnya terhadap kemampuan berpikir kreatif matematika siswa.

menggunakan instrumen yang diberi nama Matching Familiar Figures Test (MFFT) yang telah dikembangkan Warli (2010) yang berupa gambar, yang terdiri dari 2 item gambar percobaan dan 13 item gambar MFFT. Instrumen gaya kognitif dalam penelitian ini tidak dilakukan proses pengembangan karena telah dilakukan proses pengembangan oleh Warli (2010). Untuk melihat anak pada dua kelompok gaya kognitif reflektif ataupun impulsif.

Teknik pengumpulan data pada penelitian ini dengan cara melakukan tes pre test dan post test untuk tes kemampuan berpikir kreatif matematika siswa. Analisis data pada penelitian ini dengan mengikuti langkah-langkah pengujian hipotesis yaitu dengan analisis deskripsi, dan analisis inverensial yaitu terdiri dari uji normalitas, uji homognitas dan uji hipotesis.

tersaji pada rekapitulasi pada Tabel 1 berikut ini.

Tabel 1. Statistik Deskriptif $N$ Gain KBKM Siswa

\begin{tabular}{clrc}
\hline Pendekatan Pembelajaran & Gaya Kognitif & Mean & N \\
\hline \multirow{2}{*}{ Open ended } & Reflektif & 0,449 & 10 \\
& Impulsif & 0,157 & 13 \\
& Total & 0,2839 & 23 \\
Problem Posing & Reflektif & 0,266 & 13 \\
& Impulsif & 0,277 & 11 \\
& Total & 0,2713 & 24 \\
\hline
\end{tabular}


Berdasarkan tabel 1 di atas dapat dikemukakan bahwa kelas yang diajar dengan pendekatan open ended khususnya untuk kelompok siswa yang bergaya kognitif reflektif memiliki rata-rata N_Gain sebesar 0,449 yang tergolong dalam kategori sedang, sedangkan untuk kelompok siswa yang bergaya kognitif impulsif memiliki rata-rata sebesar 0,157 yang tergolong kategori rendah dimana jumlah siswa pada kelompok impulsif lebih banyak dibanding kelompok reflektifnya. Sedangkan untuk kelas yang diajar dengan pendekatan problem posing memiliki rata-rata $N \_$gain sebesar 0,266 pada kelompok reflektif yang relatif sama dengan kelompok impulsif yaitu 0,277 dan termasuk dalam $N \_G a i n$ kategori rendah sehingga secara keseluruhan $N \_G a i n$ pada kelas yang diajar dengan pendekatan problem posing tergolong rendah dengan jumlah siswa kelompok reflektif lebih banyak dibanding kelompok impulsif.

Tahap selanjutnya dalam analisis data adalah analisis inferensial. Melalui analisis inferensial kita dapat mengetahui apakah hipotesis dalam penelitian ini diterima atau ditolak. Dalam analisis inferensial, terdapat beberapa tahap analisis yang menjadi prasyarat untuk melakukan analisis uji hipotesis yaitu analisis uji normalitas data dan analisis uji homogenitas data. Analisis uji normalitas data dimaksudkan untuk mengetahui apakah data yang diperoleh berdistribusi normal atau tidak, sedangkan analisis homogenitas dimaksudkan untuk mengetahui apakah kedua kelompok data memiliki variansi yang homogen atau tidak, setelah melalui syarat uji normalitas dan homogenitas maka dilanjutkan dengan uji hipotesis.

Tabel 2. Hasil Analisis Perbedaan Peningkatan KBKM Siswa pada Kedua Kelas Eksperimen dengan Gaya Kognitif Reflektif

\begin{tabular}{|c|c|c|c|c|c|c|}
\hline \multicolumn{7}{|c|}{ Independent Samples Test } \\
\hline \multicolumn{7}{|c|}{ t-test for Equality of Means } \\
\hline \multirow[b]{2}{*}{$\mathrm{t}$} & \multirow[b]{2}{*}{$\mathrm{df}$} & \multirow[b]{2}{*}{ Sig. (2-tailed) } & \multirow{2}{*}{$\begin{array}{c}\text { Mean } \\
\text { Difference }\end{array}$} & \multirow{2}{*}{$\begin{array}{l}\text { Std. Error } \\
\text { Difference }\end{array}$} & \multicolumn{2}{|c|}{$\begin{array}{l}95 \% \text { Confidence } \\
\text { Interval of the } \\
\text { Difference }\end{array}$} \\
\hline & & & & & Lower & Upper \\
\hline 1,899 & 21 &, 071 & ,18285 & ,09627 &,- 01735 & ,38304 \\
\hline
\end{tabular}

Berdasarkan hasil analisis di atas diperoleh bahwa nilai $p$-value $=0,071>\alpha$ $=0,05$ sehingga Ho diterima. Dengan diterimanya Ho ini berarti bahwa, Tidak terdapat perbedaan pengaruh yang signifikan penerapan pendekatan open ended dan pendekatan problem possing terhadap peningkatan kemampuan berpikir kreatif matematik siswa dengan gaya kognitif reflektif.
Berdasarkan hasil analisis di atas diperoleh bahwa nilai $p$-value $=0,112>\alpha$ $=0,05$ sehingga Ho diterima. Dengan diterimanya Ho ini berarti bahwa, Tidak terdapat perbedaan pengaruh yang signifikan penerapan pendekatan open ended dan pendekatan problem possing terhadap peningkatan kemampuan berpikir kreatif matematik siswa dengan gaya kognitif impulsif. Hasil analisinya tersaji pada Tabel 3 berikut 
Tabel 3. Hasil Analisis Perbedaan Peningkatan KBKM Siswa pada Kedua Kelas Eksperimen dengan Gaya Kognitif Impulsif

\begin{tabular}{|c|c|c|c|c|c|c|}
\hline \multicolumn{7}{|c|}{ Independe nt Samples Test } \\
\hline \multicolumn{7}{|c|}{ t-test for Equality of Means } \\
\hline \multirow[b]{2}{*}{$\mathrm{t}$} & \multirow[b]{2}{*}{$\mathrm{df}$} & \multirow[b]{2}{*}{ Sig. (2-tailed) } & \multirow{2}{*}{$\begin{array}{c}\text { Mean } \\
\text { Difference }\end{array}$} & \multirow{2}{*}{$\begin{array}{l}\text { Std. Error } \\
\text { Difference }\end{array}$} & \multicolumn{2}{|c|}{$\begin{array}{c}95 \% \text { Confidence } \\
\text { Interval of the } \\
\text { Difference }\end{array}$} \\
\hline & & & & & Lower & Upper \\
\hline$-1,654$ & 22 &, 112 &,- 12035 &, 07278 &,- 27128 &, 03058 \\
\hline
\end{tabular}

Hasil pekerjaan siswa terhadap 4 butir soal tes KBKM yang diberikan menunjukkan bahwa siswa yang diajarkan dengan pendekatan open ended relatif sama dengan yang diajar dengan pendekatan problem posing. Ini terlihat dari rata-rata skor hasil pekerjaan siswa pada masing-masing soal sebelum perlakuan dan sesudah perlakuan pada kedua kelas eksperimen. Hal ini terlihat terlihat dari seluruh aspek indikator KBKM yaitu meliputi: fluency, fleksibility, originality, dan elaboration.

Hasil analisis yang dilakukan terhadap hasil kerja siswa dalam menyelesaikan tes KBKM ditinjau dari penggunaan pembelajaran yang diberikan disajikan pada Tabel 4.

Tabel 4 Rata-rata KBKM Siswa Per-Aspek pada Masing-Masing Kelas

\begin{tabular}{ccccc}
\hline \multicolumn{2}{c}{ Pretest } & item kbkm & \multicolumn{2}{c}{ Posttest } \\
$\begin{array}{c}\text { Open } \\
\text { ended }\end{array}$ & $\begin{array}{c}\text { Problem } \\
\text { posing }\end{array}$ & Open & $\begin{array}{c}\text { Problem } \\
\text { Posing }\end{array}$ \\
\hline 1,04 & 1,21 & fluency & 2,30 & 2,75 \\
1,22 & 1,42 & fleksibility & 2,74 & 2,79 \\
0,57 & 0,71 & originality & 0,78 & 0,83 \\
0,83 & 1,00 & elaboration & 2,09 & 1,96 \\
\hline
\end{tabular}

Tabel 4 menunjukkan bahwa secara umum terjadi peningkatan KBKM pada setiap indikator. Indikator originality yaitu kemampuan untuk melahirkan ide-ide yang baru dan memikirkan cara yang tidak lazim agar dapat mengungkapkan diri serta mampu membuat berbagai kombinasi yang tidak lazim dari bagian-bagian atau unsur-unsur konsep yang sudah dipelajari ini masih sangat rendah. Hal ini

\section{PEMBAHASAN}

Hasil analisis data baik dari analisis deskriptif maupun analisis inferensial menunjukkan bahwa terdapat pengaruh pembelajaran pendekatan open ended dan pendekatan Problem posing terhadap dikarenakan siswa tidak terbiasa dengan masalah-masalah nyata yang diselesaikan dengan berbagai alternatif jawaban. Secara keseluruhan semua aspek mengalami peningkatan baik sebelum dan sesudah perlakuan namun masih dalam kategori yang rendah artinya indikator yang diharapkan muncul belum maksimal.

peningkatan kemampuan berpikir kreatif matematika. Tetapi setelah membandingkan peningkatan kemampuan berpikir kreatif matematika siswa kedua kelas melalui uji statistik inferensial, 
diperoleh hasil bahwa tidak terdapat perbedaan pengaruh yang signifikan antara pendekatan open ended dan pendekatan Problem posing terhadap peningkatan kemampuan berpikir kreatif matematika siswa baik ditinjau dari keseluruhan siswa maupun ditinjau dari gaya kognitif siswa. Hal ini terlihat pada nilai rata-rata N-Gain kedua kelompok yang menyimpulkan bahwa nilai rata-rata $\mathrm{N}$-Gain kemampuan berpikir kreatif matematika kelompok siswa yang pembelajarannya menggunakan pendekatan open ended relatif sama dibandingkan nilai rata-rata N-Gain kelompok siswa yang pembelajarannya menggunakan pendekatan Problem Posing.

Dari kesimpulan yang dikemukakan di atas, dapat dikatakan bahwa faktor pendekatan pembelajaran berpengaruh signifikan terhadap peningkatan kemampuan berpikir kreatif matematika siswa. Tetapi kedua pendekatan pembelajaran dalam penelitian ini tidak memiliki pengaruh yang berbeda terhadap peningkatan kemampuan berpikir kreatif matematika siswa. Meskipun kedua prinsip pelaksanaan pendekatan pembelajaran berbeda.

Penyebab tidak adanya perbedaan pengaruh kedua pendekatan pembelajaran terhadap peningkatan kemampuan berpikir kreatif matematika kedua kelas tersebut adalah karena siswa senang dan aktif dalam proses pembelajaran dengan menggunakan pendekatan open ended dan pendekatan Problem Posing. Siswa sangat antusias dengan hal baru yang dilakukan oleh peneliti. Hal ini disebabkan oleh model pembelajaran yang diterapakan baik pendekatan open ended dan model pembelajaran Pendekatan problem posing sama-sama berfungsi dengan baik dalam mengangkat hasil belajar siswa-siswa yang bergaya kognitif reflektif maupun impulsif. Terlihat juga dari kedua model pembelajaran memiliki rata-rata dengan selisih tidak lebih dari satu. Ini sejalan dengan penelitian yang dilakukan Ani
Fitriyani (2015) menyebutkan bahwa pembelajaran menggunakan pendekatan open ended berdampak positif untuk kemampuan berpikir kreatif peserta didik, sebab dalam pembelajaran ini peserta didik banyak disediakan soal-soal yang memicu kemampuan analisis dan berpikir tingkat tinggi. Dalam pembelajaran ini peserta didik dituntut untuk dapat menyelesaikan lebih dari satu cara ataupun jawaban benar sesuai dengan pengalaman mengaitkan pembelajaran satu dengan yang lain. Secara tidak langsung peserta didik memaksimalkan kemampuan berpikir kreatif mereka. Kemudian Leung (1997:81) menjelaskan bahwa kreativitas dan pengajuan masalah mempunyai sifat yang sama dalam keserbaragamannya. "Pembuatan sebuah masalah" yang merupakan ciri pengajuan masalah dan sifat "membawa menjadi ada" yang merupakan sifat kreativitas memungkinkan untuk memandang bahwa pengajuan masalah merupakan suatu bentuk kreativitas. Pendapat di atas melihat bahwa kreativitas sebagai produk berpikir kreatif berkaitan dengan pengajuan masalah dan pengajuan masalah dapat merupakan sarana untuk menilai/mengukur kemampuan kreatifitas siswa.

Selanjutnya gaya kognitif ditinjau dari pendekatan pembelajaran mempunyai perbedaan pengaruh yang signifikan hanya pada kelas yang diajar dengan pendekatan open ended. Hal ini menunjukan bahwa kemampuan berpikir kreatif matematika untuk siswa yang memiliki gaya kognitif reflektif dan siswa yang memiliki gaya kognitif impulsif memiliki perbedaan untuk pendekatan open ended.

Hal ini terjadi karena kedua gaya kognitif tersebut memiliki perbedaan yang cukup signifikan. Gaya kognitif impulsif adalah gaya kognitif siswa yang memiliki karakteristik dalam menjawab masalah secara cepat tetapi tidak cermat/tidak teliti sehingga jawaban cenderung salah, sedangkan gaya kognitif reflektif adalah 
gaya kognitif siswa yang memiliki karakteristik dalam menjawab masalah secara lambat, tetapi cermat/teliti sehingga jawaban cenderung betul.

Kelompok siswa impulsif dalam pelaksanaan tes terlihat kurang berkonsentrasi. Mereka sering terlihat mengobrol atau sibuk dengan kegiatannya sendiri. Saat diwawancara dan diberi pertanyaan mengenai waktu, sebagian besar dari mereka menjawab waktu yang diberikan kurang. Alasan inilah yang diutarakan beberapa siswa impulsif mengapa mereka belum selesai mengerjakan seluruh soalnya. Waktu yang ditentukan sebenarnya sudah cukup, namun beberapa siswa ini tidak memanfaatkannya dengan baik. Pada saat pengoreksian, terlihat banyak pekerjaan yang belum selesai dan banyak jawaban yang salah akibat kurangnya ketelitian siswa. Mereka hanya sekedar membuat soal dan ingin segera mengakhiri pelaksanaan tes. Tidak hanya itu, ada pula siswa yang berpendapat bahwa waktu yang diberikan terlalu banyak, sehingga saat pelaksanaan tes siswa ini terlihat bosan. Saat pengoreksian berlangsung, ternyata pekerjaannya juga masih banyak yang belum dikerjakan. siswa reflektif lebih tenang dan serius saat mengerjakan. Mereka lebih memilih berkonsentrasi saat melakukan pekerjaannya dibandingkan dengan mengobrol atau sekedar bersenda guaru dengan teman di sebelahnya.

Hal ini juga dapat dilihat dari hasil tes berpikir kreatifnya. Kelompok siswa reflektif memiliki hasil tes yang cukup memuaskan dibandingan dengan kelompok siswa impulsif. Hal tersebut yang membedakan anak dalam menyelesaikan suatu masalah terutama dalam menyelesaikan masalah dalam kelompok belajar. Siswa yang memiliki gaya kognitif relektif cenderung hati-hati dalam menyelesaikan suatu masalah dibandingan dengan siswa yang memiliki gaya kognitif impulsif. Hal ini sesuai dengan Abdurrahman (1999) menyatakan bahwa gaya kognitif impulsif-reflektif terkait dengan penggunaan waktu yang digunakan siswa untuk menjawab persoalan dan jumlah kesalahan yang dibuat, dengan ketidakpastian jawaban. Siswa yang impulsif cenderung menjawab masalah secara cepat tetapi banyak membuat kesalahan, sedangkan siswa reflektif cenderung menjawab masalah secara lebih lambat tetapi hanya sedikit salahnya.

Kelas yang diajar dengan pendekatan problem posing terdapat pengaruh yang tidak signifikan antara siswa dengan gaya kognitif reflektif dan siswa dengan gaya kognitif impulsif. Hal ini menunjukkan bahwa kemampuan berpikir kreatif siswa dalam hal ini relatif sama. Ini terjadi karena siswa masih kesulitan menyesuaikan diri dengan teman kelompok barunya yang telah dibentuk guru berdasarkan kelompok gaya kognitif reflektif dan gaya kognitif impulsif. Mereka masih cenderung kurang aktif dan masih malu-malu mengemukakan pendapat dan menyelesaikan masalah yang diberikan guru, utamanya siswa masih merasa aneh ketika dihadapkan pada soalsoal yang mempunyai penyelesaian lebih dari satu cara.

Penelitian ini mengemukakan bahwa pada kelas yang diajar dengan pendekatan open ended sebagian besar siwa yang memiliki gaya kognitif reflektif mempunyai peningkatan kemampuan berpikir kreatif matematika yang sedang dan siswa dengan gaya kognitif impulsif menunjukkan peningkatan yang rendah. Pada dasarnya pendekatan open-ended dalam pembelajaran matematika bertujuan menciptakan suasana pembelajaran agar siswa memperoleh pengalaman dalam menemukan sesuatu yang baru melalui proses pembelajaran. Tujuan pembudayaan pembelajaran matematika dengan open-ended adalah membantu mengembangkan aktivitas dan berpikir matematik siswa secara serempak dalam pemecahan masalah (Hudiono, 2008 : 23). 
Menurut Suherman, tujuan pendekatan open-ended bukan untuk mendapatkan jawaban tetapi lebih menekankan pada cara bagaimana sampai pada suatu jawaban. Dengan demikian, bukanlah hanya satu cara dalam mendapatkan jawaban, namun beberapa atau banyak cara (Asriah, 2011: 10). Aktivitas siswa dalam pembelajaran dengan pendekatan open ended berlangsung secara optimal mulai dari aktivitas dalam kelompok untuk menyelesaikan masalah yang telah disajikan dalam LKS, maupun aktivitas dalam kelas untuk berinteraksi terhadap kelompok lain melalui diskusi kelas. Masalah yang disajikan dalam LKS berupa masalah-masalah yang penyelesaiannya membutuhkan banyak cara atau masalah yang mempunya banyak solusi jawaban benar. Dengan demikian, siswa dalam kelompoknya mampu mengeksplorasi berbagai ide-ide dalam pemecahan masalah.

Pada penelitian ini, problem posing yang digunakan adalah pengajuan masalah dari soal-soal yang telah diberikan, siswa secara kreatif menemukan atau mengajukan masalah lain dari soal yang telah ada, mengembangkan ide-idenya dari informasi atau pengetahuan yang dimilikinya. Siswa dapat secara terstruktur mengaitkan informasi dan prinsip-prinsip matematika dalam menyelesaikan masalah matematika. Siswa menyelesaikan masalah kreatif dan mampu membuat masalah lain terkait masalah yang diberikan dan mampu menyelesaikanya dengan baik. Masalah-masalah yang diberikan dirancang untuk menumbuhkan kreatifitas siswa dlam pengajuan masalah baik untuk siswa dengan gaya kognitif reflektif maupun dengan gaya kognitif impulsif.

Melalui kegiatan pembelajaran yang dirancang sesuai dengan prinsip dan karakteristik pendekatan open ended dan karakteristik problem posing yang memungkinkan munculnya indikatorindikator kemampuan berpikir kreatif matematika siswa. Hal ini dapat dilihat pada proses pembelajaran dan cara siswa menjawab soal-soal tes kemampuan berpikir kreatif yang diberikan yaitu kelancaran berpikir (fluency), keluwesan berpikir (fleksibility), keaslian (originality), dan keterincian (elaboration).

Berdasarkan empat indikator kemampuan berpikir kreatif yang dikembangkan eksperimen ini, telah disusun 4 butir soal yang digunakan untuk mengukur penguasan siswa terhadap kemampuan tersebut. Hasil pekerjaan siswa terhadap 4 butir soal tes kemampuan berpikir kreatif matematika siswa yang pembelajarannya menggunakan pendekatan open ended relatif sama dengan siswa yang pembelajaranya menggunakan pendekatan problem posing. Ini terlihat pada rata-rata masing-masing indikator pada setiap kelas eksperimen baik pada pretest maupun posttest. Dari keekmpat indikator tersebut yang nampak paling rendah adalah indikator originality.

Dalam penelitian ini, kriteria originality pada kedua kelas tidak tercapai dengan baik. Secara umum rata-rata peningkatan untuk kedua kelas sangatlah rendah jika dibandingkan dengan kriteria yang lain. Tidak ada satupun siswa baik itu gaya kognitif reflektif maupun impulsif yang dapat memenuhi kriteria ini. Kelompok impulsif dan refkeltif berpendapat bahwa sangatlah sulit menentukan penyelesaian masalah dengan cara mereka sendiri karena mereka terbiasa dengan masalah yang sama persis dengan yang diberikan guru atau bersifat konseptual. Dimana originality adalah kemampuan untuk melahirkan ide-ide yang baru dan memikirkan cara yang tidak lazim agar dapat mengungkapkan diri serta mampu membuat berbagai kombinasi yang tidak lazim dari bagian-bagian atau unsur-unsur. Sedangkan untuk setiap indikator fluency, fleksibility, dan elaboration masing-masing kelas menunjukkan rata-rata peningkatan yang 
tidak jauh berbeda. Ini artinya siswa mampu secara lancar, luwes dan terinci menyelesaikan masalah jika diberikan contoh yang serupa tapi kurang mampu mengemukakan ide atau gagasannya sendiri dalam menyelesaikan masalah yang diberikan ataupun mengajukan masalah baru.

Dari pernyataan di atas, dengan diterapkanya pendekatan open ended dan pendekatan problem posing untuk meningkatkan kemampuan berpikir kreatif matematika siswa baik itu siswa dengan gaya kognitif maupun siswa dengan gaya kognitif impulsif. Dengan pembelajaran secara berkelompok siswa akan mudah mendapatkan solusi dari permasalahan yang diberikan. Hal ini didukung oleh pendapat Arends (2008) dan Trianto (2009) yang menyatakan bahwa dengan bekerja bersama dapat memberikan motivasi dan dapat mengembangkan keterampilan sosial dan keterampilan

\section{KESIMPULAN DAN SARAN}

Kesimpulan yang diperoleh pada penelitian ini antara lain keberhasilan proses pembelajaran siswa yang diajar dengan pendekatan pembelajaran open ended dan pendekatan problem posing relatif sama. Pada kelas yang diajar dengan pendekatan pembelajaran open ended dan pendekatan problem posing menunjukkan rata-rata yang relatif sama baik itu pada kelompok siswa dengan gaya kognitif reflektif maupun dengan gaya kognitif impulsive dan Secara umum kelompok siswa yang bergaya kognitif reflektif pada kelas yang diajar dengan

\section{DAFTAR PUSTAKA}

Amalina, Ijtihadi.K., Tatag Yuli Eko.S., 2016. Investigasi Kemampuan Berpikir Kreatif Siswa dalam Pengajuan Masalah Matematika. Jurnal Ilmiah Pendidikan Matematika, 2(5). berpikir. Pada tahap akhir, guru bersama siswa melakukan penilaian terhadap hasil diskusi kelompok dengan cara siswa mempresentasikannya di depan kelas kemudian siswa yang lain mengoreksi hasil presentasi.

Hal ini didukung oleh pendapat Trianto (2009) yang menyatakan bahwa pada tahap akhir pembelajaran, tugas guru membantu siswa meng-analisis dan mengevaluasi proses berpikir mereka sendiri dan keterampilan penyelidikan yang mereka gunakan. Karena dengan mengoreksi hasil pekerjaannya mereka sendiri dapat meningkatkan kemampuan anak dalam menyelesaikan soal. Hal ini didukung oleh Suherman (2001) yang menyatakan bahwa mempertimbangkan kembali proses penyelesaian yang telah dibuat merupakan faktor yang sangat signifikan untuk meningkatkan kemampuan anak.

pendekatan open ended mengalami peningkatan kemampuan berpikir kreatif matematika yang lebih tinggi dari kelas yang diajar dengan pendekatan problem posing. Sedangkan untuk kelompok siswa yang bergaya kognitif impulsif pada kedua kelas relatif sama.

Saran yag dapat dikemukakan dari hasil penelitian ini yaitu agar guru memperhatikan gaya kognitif siswa dan perlunya penerapan pendekatan open ended dan problem posing dalam pembelajaran matematika.

Anita, E Woolfolk. 1993. Educational Psychology. London: Allyn and Bacon.

Barlow, Angela T., \& Cates, Janie M. 2006. The Impact of Problem posing on Elementary Teachers' Beliefs about Mathematics and Mathematics 
Teaching. School Science and Mathematics, 106 (2) : 64-73.

Baroody, A. J. 1993. Problem Solving, Reasoning and Communicating, $K$ 8: Helping Children Think Mathematically. New York: McMillan Publishing Company.

Ellerton dan Jinfa Cai (Ed). 2015. Mathematical Problem posing : From Research to Effective Practice. New York : Springer.

Brown, S. \& Walter, R.. 1990. The Art of Problem Posing. London: Lawrence Erlbaum Associates Publishers.

Goldstein, Norman L., \& E Brophy. 1990. Education Psycholog. New York, Longman.

Heineman, Peter L. 1995. Cognitive and Learning Style, Boston, Allyn \& Bacon.

Hudiono dan Bambang. 2008. Pembudayaan Pendekatan OpenEnded Problem Solving dalam Pengembangan Daya Representatif Matematik pada Siswa Sekolah Menengah Pertama. Jurnal Pendidikan Dasar, 9(1).

Myrmel, M. Kay. 2003. Effects Of Using Creative Problem Solving In Eighth Grade Technology Education Class At Hopkins North Junior High School. Tesis: The Graduate School University Of Wisconsin-Stout.

National Council of Teachers of Mathematics (NCTM). 2000. Principles and Standards for School Mathematics. Drive, Reston, VA: The NCTM

OECD. 2014. PISA 2012 Results: Creative Problem Solving, Students' Skills In Tackling Real-Life Problems (Volume V). PISA, OECD Publishing.[Online]. Tersedia: http://dx.doi.org/10.1787/978926420 8070-en
Riding, RJ., Glass, A.,\& Douglas, G. 1993. Individual Differences in Thinking: Cognitive and Neurophysiological Perspectves, Special Issue: Thinking, Educational Psychology, 13 (3 \& 4): 267-279.

Silver, E.A. 1994. "On Mathematical Problem Posing". For the Learning of Mathematics. (1): 19-28.

Silver, Edward A and Cai, Jinfa 1996. An Analysis of Arithmetic Problem posing By Middle School Students. Journal For Research In Mathematics Education, 27(5): 521539.

Singer, Florence Mihaela, \& Voica, Cristian. 2015. "Is Problem posing a Tool for Identifying and Developing Mathematical Creativity?". Dalam Florence Mihaela Singer, Nerida F. Ellerton dan Jinfa Cai (Ed). 2015. Mathematical Problem posing : From Research to Effective Practice. New York : Springer.

Suherman. 2003. Evaluasi Pendidikan Matematika. Bandung: Wijaya kusumah.

Warli. 2010. Profil Kreativitas Siswa yang Bergaya Kognitif Reflektif dan Siswa yang Bergaya Kognitif Impulsif dalam Memecahkan Masalah Geometri. Disertasi tidak diterbitkan. Surabaya: PPS-Unesa.

Woolfolk, A. 2007. Educational psychology (10th ed). Boston, MA: Pearson Educational Inc. 